\title{
A rendőrség személyvédelmi feladatai - visszatekintés az elmúlt 10 évre
}

\section{NAGY Tamás ${ }^{1}$}

\begin{abstract}
Az állami rendészet elmúlt tíz évét olyan folyamatos változás jellemezte, amely a feladat- és hatáskörök módosításától egészen az új intézmények létrehozásáig terjedt. A hazai rendészetnek kevés olyan területe van, amelynek átalakítása annyira szerteágazó lett volna, mint a személyvédelem esetén. Az elmúlt tíz évben nemcsak a jogszabályi környezet (szabályozás), hanem a korábbi intézményrendszer (szervezet), valamint az ehhez kapcsolódó feladat- és hatáskörök (müködés) is gyökeresen megváltoztak. A folyamat teljes egészében átalakította a tevékenység hátterét, olyannyira, hogy az - bizonyos szempontból - a terület reformjaként is értelmezhető. A Magyarország érdekei szempontjából különösen fontos személyek védelme a rendészet kevésbé ismert területei közé tartozik, bár jelentősége vitathatatlan. E tanulmány célja, hogy röviden bemutassa az elmúlt évek személyvédelmet érintő változásait, és ismertessem ezek hatását a terület 2010 utáni müködésére.
\end{abstract}

Kulcsszavak: személyvédelem, Magyar Rendörség, különösen fontos személy, Készenléti Rendőrség, Országgyülési Örség, Terrorelhárítási Központ

\section{Bevezető gondolatok}

2020 decemberében több napilap is beszámolt arról, hogy a kormány megszünteti a Kúria elnökének személyi védelmét, aki a továbbiakban a minisztereknek járó szolgáltatásokat - a Készenléti Rendőrség által biztosított felső középkategóriás gépjármúvet és biztonsági gépjármúvezetőt - vesz csak igénybe. ${ }^{2} \mathrm{~A}$ bejelentés a széles publikum számára nem rendelkezik különösebb hírértékkel, szakmai szempontból azonban érdekes folyamatra világít rá, mivel a Kúria (korábban: Legfelsőbb Bíróság) mindenkori elnöke egyike azon állami vezetőknek, akik - 1997. január 1-je

Dr. Nagy Tamás rendőr főhadnagy, megbízott kiemelt főnyomozó, Készenléti Rendőrség-Nemzeti Nyomozó Iroda, Kiberbűnözés Elleni Főosztály, Felderítő Osztály; doktori hallgató, Nemzeti Közszolgálati Egyetem Rendészettudományi Doktori Iskola.

Tamás Nagy Police First Lieutenant, Chief Investigator, Rapid Response and Special Police Services, National Bureau of Investigation, Cybercrime Department, Criminal Intelligence Division; PhD student, University of Public Service Doctoral School of Police Sciences and Law Enforcement.

E-mail: nagy.tommike@gmail.com, ORCID: https://orcid.org/0000-0002-7230-2548

2 Azt nem tudni pontosan, hogy a változás összefügg-e azzal a ténnyel, hogy a Kúria új elnöke 2021. január 1-jén lépett hivatalba. 
óta ${ }^{3}$ - állandó személyi védelemre jogosultak. Ekkor lépett életbe a védett személyek és kijelölt létesítmények védelméről szóló 160/1996. (XI. 5.) kormányrendelet, amely hosszú időn keresztül - egyedüli jogszabályként - a határozta meg azt, hogy mely közjogi tisztségek védelme kötelező, illetve e védelem milyen szakmai keretek között valósul meg. A rendelet szövegének különböző változásai híven tükrözik a terület (személyvédelem) elmúlt években lezajló átalakulását. Míg 1997 és 2010 között a védett személyek köre, illetve az ehhez kapcsolódó intézményi háttér - kisebb módosításoktól eltekintve - szinte alig változott, addig 2010 után ez a folyamat felgyorsult és beindult egy széles körú átalakulás, amely egyaránt érintette a személyvédelem szervezeti, működési és szabályozási kérdéseit is. A folyamatos változás ellenére két évtized után ez volt az első alkalom, hogy az állandó védelemben részesülő személyek köre oly módon változott meg, hogy e körből valamely közjogi tisztség kikerült. Ahhoz, hogy egy ilyen jellegű változás jelentőségét átlássuk, fontos megemlíteni azt, hogy a legfőbb közjogi méltóságokat érintő veszélyeztetettség az állam zavartalan múködését is érinti. Az állam, illetve az államhatalmi szervek múködésének biztosítása pedig megfelelő okot biztosít arra, hogy védett állami vezetők köre ${ }^{4}$ valamennyi országban - így hazánkban is - csak a legritkább esetben változik. A 2010 óta lezajló folyamatok pontosabb megértéséhez emiatt (is) elengedhetetlen a személyvédelem rendszerváltás utáni háttérének rövid bemutatása, mivel a későbbi folyamatok csak ezt figyelembe véve értékelhetők megfelelően.

\section{A személyvédelem helye és szerepe a rendszerváltást követöen}

A rendszerváltást követően elindult egy széles körű gazdasági-társadalmi átalakulás, amely az állami intézményrendszert sem hagyta érintetlenül. Ahogy a közigazgatás más szegmenseiben is, ${ }^{5}$ úgy a rendészeti szervek kapcsán is felmerült az igény, hogy felülvizsgálják a rendészeti szervek felépítését vagy éppen múködését. ${ }^{6} \mathrm{Ez}$ a folyamat a Belügyminisztérium szervezeti átalakítása ${ }^{7}$ révén a Kormányőrséget sem kerülhette el, amely a szocializmus alatt a pártvezetők, állam- és kormányfők védelmét ${ }^{8}$ volt hivatott ellátni. A rendszerváltás során a testület tevékenysége lényegében nem változott, azonban hivatalos elnevezése kapcsán több változás is történt. A Kormányőrség elnevezés - utalva a demokratikus átalakulásra - 1990. január 1-jétől átmenetileg

3 A védett személyek és kijelölt létesítmények védelméről szóló 160/1996. (XI. 5.) kormányrendelet 1. sz. melléklete alapján.

4 E személyek köre nem esik egybe a 160/1996. (XI. 5.) kormányrendeletben szereplő személyekkel, ugyanis idetartozik még az Országgyülés elnökének külön jogszabályban (Ogytv.) meghatározott védelme is.

Balla Zoltán: A rendészet alapjai és egyes ágazatai. Budapest, Dialóg Campus, 2017. 42.

Finszter Géza: Rendészettan. Budapest, Dialóg Campus, 2018. 113.

53/1990. BM utasítás a Belügyminisztérium szervezetéről és belső rendjéről.

A BM Kormányőrség ügyrendje (10-650/1972.) alapján idetartoztak az MSZMP Politikai Bizottság tagjai, a Központi Bizottság titkárai, a Magyar Népköztársaság Elnöki Tanácsának elnöke, a Magyar Forradalmi Munkás-Paraszt Kormány elnöke és elnökhelyettesei, valamint a hazánkban tartózkodó vagy átutazó, hasonló szintű párt, állami és kormányvezetők, továbbá az MSZMP Politikai Bizottsága által meghatározott más magyar és külföldi személyek. 
Magyar Köztársaság Kormányőrségére, majd 1992. január 1-jén Köztársasági Őrezredre változott. A rendszerváltás után a BM Rendészeti Hivatal alá tartozó testületet a Hivatal 1993. május 1-jei megszúnését követően integrálták az Országos Rendőr-főkapitányságba (ORFK), ahol az ORFK főigazgatóság jogállású szervként folytatta múködését. ${ }^{9}$

A strukturális átalakítások mellett a reformtervek részét képezte a rendészeti szervezetrendszer felülvizsgálata is, amely különösen a rendőrség esetében volt elengedhetetlen. Ennek több oka is volt: egyrészt e szervezet rendelkezett a legnagyobb létszámú állománnyal, másrészt (a szocialista éra alatt kialakult) politikai kötöttsége miatt társadalmi megítélése igen kedvezőtlen volt, nem mellesleg a rendszerváltás utáni években hatékonysági problémákkal is meg kellett küzdenie. Abban az elméleti és gyakorlati szakemberek többsége egyetértett, hogy az átalakítás garanciát jelenthet arra, hogy - ha a folyamat sikeres - az újonnan kialakított (vagy létrehozott) szervezeti struktúra megfelel majd a kor kihívásainak. Ehhez elengedhetetlen volt egy önálló rendőrségi törvény megalkotása, mivel a korábbi működés (a legtöbb esetben) jogi garanciák nélkül valósult meg. A rendőrség múködése szempontjából a kodifikációs munka azért is volt különösen fontos, mivel azzal a rendőrség egységes, átlátható és modern szabályozását kívánták megteremteni. A jogalkotási folyamat fontos szempontja volt, hogy az új törvény rendezze a testület feladat- és hatáskörét, illetve meghatározza a szervezetre (valamint annak állományára) vonatkozó jogokat és kötelezettségeket. A személyvédelem szempontjából ez azért is fontos körülmény, mivel a tevékenység - a Köztársasági Őrezred integrációja révén - 1993. január 1-je után a rendőrség feladatkörébe került, így a feladat- és hatáskör normatív kialakításával e kérdést is rendezni lehetett. A Rendőrségről szóló 1994. évi XXXIV. törvény (Rtv.) hatálybalépésével a Magyar Köztársaság érdekei szempontjából különösen fontos személyek védelmét a jogalkotó - rendészeti feladatként - az elsődleges rendészeti szerv $^{10}$ (Országos Rendőr-fökapitányság) feladat- és hatáskörébe utalta. A törvény szövege ezt az alábbiak szerint fogalmazta meg:

„A Rendőrség a közbiztonság és a belső rend védelme körében az e törvényben és törvény felhatalmazása alapján más jogszabályban meghatározott bűnmegelőzési, bűnüldözési, államigazgatási és rendészeti feladatkörében:

g) védi a Magyar Köztársaság érdekei szempontjából különösen fontos személyek (a továbbiakban: védett személy) életét, testi épségét, őrzi a kijelölt létesítményeket;"

A tevékenység szakmai kereteinek kialakítása ekkor azonban még volt teljes körű, mivel az Rtv. csak a tevékenység intézményi kereteit adta meg, a védelem módját és részletszabályait, így a védett (különösen fontos) személyek körét sem határozta

Verebélyi Imre (szerk.): Rendszerváltozás és modernizáció a belügyi közigazgatásban (1989-1994). Budapest, Dialóg Campus, 2020. 245.

10 Balla (2017) i. m. 45. 
meg pontosan. Ezt a kérdést a feladathoz kapcsolódó végrehajtási rendelet, a 160/1996. (XI. 5.) kormányrendelet rendezte, amelynek 1. melléklete az alábbiak szerint jelölte ki az állandó személyvédelemben részesülő állami vezetők körét:

- a Magyar Köztársaság elnöke;

- a Magyar Köztársaság miniszterelnöke;

- a Magyar Országgyúlés elnöke;

- a Magyar Köztársaság Alkotmánybíróságának elnöke;

- a Magyar Köztársaság Legfelsőbb Bíróságának elnöke.

E felsorolás a szakmai terminológiába is beépült, olyannyira, hogy személyvédelem alatt - általános értelemben ${ }^{11}$ és - elsődlegesen a legfőbb közjogi méltóságok (a hatályos szabályozás alapján: különösen fontos személyek) védelmét szokás érteni. Az állandó jellegű személyvédelem legfontosabb jellemzői az alábbiak:

- alanyai a Magyarország (vagyis az állam múködése) szempontjából különösen fontos személyek;

- jogszabály rendelkezik az állandó védelemre jogosult személyek köréről, a védelem nem konkrét személyhez, hanem meghatározott tisztséghez igazodik;

- a személyi védelem a tisztség betöltése alatt (bizonyos feltételek esetén azt megelőzően, illetve azt követően is) folyamatos, arról lemondani csak jogszabály külön engedélye alapján (előzetesen és írásban) lehet;

- a személyi védelemhez kapcsolódó szakmai feladatok (végrehajtás) olyan rendészeti szervek feladat- és hatáskörébe tartoznak, amelyek rendelkeznek a feladat végrehajtásához szükséges, speciálisan képzett apparátussal.

A felsorolt kritériumok azért is fontosak, mivel azokban visszaköszön a tevékenységhez kapcsolódó szervezeti, valamint működési és szabályozási keretek.

A különösen fontos személyek védelme mellett fontos megemlíteni azt is, hogy a normaszövegbe nem csak a rendőrség korábbi tevékenységei kerültek be, a törvény ugyanis kettős (személyvédelmi) feladatkörrel ruházta fel a rendőrséget, amely egyrészt a különösen fontos személyek védelmére, másrészt a - piaci szektor - személyvédelmi tevékenységével kapcsolatos későbbi szakhatósági feladatokra is kiterjedt. E rendelkezés külön érdekessége, hogy a piaci alapon nyújtott szolgáltatás tényleges szabályozására ${ }^{12}$ jóval később, csak az 1998. évi IV. törvény ${ }^{13}$ alapján került sor. ${ }^{14}$

11 Bizonyos szempontból személyvédelmi tevékenységként értékelhető a tanúvédelemnek az a formája is, amelyet a 2001. évi LXXXV. törvény Védelmi Programnak nevez. Ez egy olyan összetett tevékenységet takar, amely - egyebek mellett - szintén a fizikai veszélyek elhárításához szükséges résztevékenységeket (személybiztosítás, lakásbiztosítás, utazás biztosítása stb.) foglal magában, viszont elrendelése - ellentétben a különösen fontos személyek védelmével - nem jogszabályon alapuló automatizmus, hanem a felek magánjogi szerződésének eredménye.

12 A személy- és vagyonvédelmi, valamint a magánnyomozói tevékenységet átmeneti jelleggel a 87/1995. (VII. 14.) kormányrendelet szabályozta.

13 1998. évi IV. törvény a vállalkozás keretében végzett személy- és vagyonvédelmi, valamint a magánnyomozói tevékenység szabályairól, a Személy-, Vagyonvédelmi és Magánnyomozói Szakmai Kamaráról.

14 Nagy Tamás - Lukács Zsolt: A személyvédelem rendészeti jellemzői és magánbiztonsági szerepe. In Christián László - Major László - Szabó Csaba (szerk.): Biztonsági vezetôi kézikönyv. Budapest, Ludovika Egyetemi Kiadó, 2019. 169. 
A személyvédelem rendészeti szerepének kialakítása a rendőrségi törvény, illetve a végrehajtási rendelet hatálybalépésével véglegesnek tekinthető. A tevékenység az Rtv. alapján - követve az intézményi háttér alakulását - az Országos Rendőrfőkapitányság feladat- és hatáskörébe került, a tényleges végrehajtásért azonban - a rendelet alapján - a Köztársasági Őrezred (mint az ORFK főigazgatóság jogállású szerve) volt felelős. ${ }^{15} \mathrm{Az}$ így kialakított intézményi és múködési háttér 2010-ig alig változott. ${ }^{16}$

\section{Változások kora}

A 2010-es kormányalakítást követően elindult egy átfogó közigazgatási reform, amely - hasonlóan az 1990 és 1994 közötti időszakhoz - széles körű intézményi és egyéb átalakulást eredményezett. A rendőrség vonatkozásában a legfontosabb változást az ágazati joganyag, ezen belül pedig a rendőrségi törvény módosítása jelentette, ami jelentősen átrendezte a korábbi viszonyokat. ${ }^{17}$ A legalapvetőbb változást a rendőrség szervezeti felépítésének módosítása jelentette, amellyel - az általános rendőrségi feladatok ellátására létrehozott szerv (ORFK) mellett - két újabb rendőri szerv jött létre. A rendőrségi törvénybe beépülő rendelkezés ${ }^{18}$ a rendőrség felépítését így határozta meg:

„A rendőrséget az általános rendőrségi feladatok ellátására létrehozott szerv, a belső bűnmegelőzési és bűnfelderítési feladatokat ellátó szerv, valamint a terrorizmust elhárító szerv alkotja." ${ }^{19}$

A személyvédelem szempontjából e rendelkezés azért volt aktuális, mivel a Terrorelhárítási Központ létrehozásával, ${ }^{20}$ majd terrorizmust elhárító szervként történő kijelölésével a kormány - a Magyarország terrorfenyegetettségével kapcsolatos rendészeti feladatok mellett - a miniszterelnök és a köztársasági elnök személyvédelmi feladatait is e szerv feladatkörébe utalta. ${ }^{21}$ A Terrorelhárítási Központ 2010. szeptember 1-jén jött létre, kijelölt feladatait pedig hivatalosan ${ }^{22}$ 2011. január 1-jétől látja el. A személyvédelmi hatáskörök részleges átruházásával megszűnt az a korábbi helyzet, amely alapján a Köztársasági Őrezred volt hazánkban az egyetlen olyan rendőri szerv,

\footnotetext{
69/1997. (XII. 29.) BM rendelet a Köztársasági Örezred feladatáról, hatásköréről és illetékességéről.

16 A jogszabály módosítása alapján rövid ideig a polgári nemzetbiztonsági szolgálatokat felügyelő tárca nélküli miniszter is állandó védelemben részesült, ez viszont 2002 májusában megszűnt.

17 Christián László: A rendőrségre és a titkosszolgálatokra vonatkozó szabályozás változásai. MTA Law Working Papers, (2014), 43. 4.

18 2010. évi CXLVII. törvény egyes rendészeti tárgyú és az azokkal összefüggő törvények módosításáról 9. §.

19 1994. évi XXXIV. törvény a Rendőrségről 4. § (2) bekezdés (2019. VII. 1. előtti állapot).

20 232/2010 (VIII. 19.) Korm. rendelet a Terrorelhárítási Központról.

21 295/2010 (XII. 22.) Korm. rendelet a terrorizmust elhárító szerv kijelöléséről és feladatai ellátásának részletes szabályairól 3. § (1) bekezdés d) pont.

22 A miniszterelnökkel és a köztársasági elnökkel kapcsolatos személyvédelmi feladatokat 2010. szeptember 1-je után már a Terrorelhárítási Központ látta el.
} 
amely a különösen fontos személyek védelmével kapcsolatos feladatokat látott el. Fontos megjegyezni, hogy a jogszabály nem csak a személyvédelmi feladatok felosztása mentén módosult, mivel ezzel egy időben az állandóan védett személyek köre is bővült, abba ugyanis bekerült a legfőbb ügyész, akinek személyi védelmét az Őrezred biztosította. Emellett fontos változást hozott a rendészeti joganyag másik eleme, a 2012-ben hatályba lépő új Szolgálati Szabályzat ${ }^{23}$ is, amely - a korábbi szabályzat ${ }^{24}$ személy- és objektumvédelemmel kapcsolatos rendelkezéseinek megtartása mellett - kibővítette a személyvédelmi szolgálati forma elemeit, ${ }^{25}$ és nevesítette a személyvédelmi feladatot ellátó szerveket.

A következő jelentős változásra sem kellett sokáig várni, ugyanis a rendőrség szerveinek feladat- és hatásköréről szóló 329/2007. (XII. 13.) kormányrendelet 2012-es módosításával megszűnt a Köztársasági Őrezred, amelynek feladatait (és állományát) a Készenléti Rendőrség (KR) vette át. ${ }^{26} \mathrm{~A}$ személyvédelmi feladatok kapcsán ez érdemi változást nem hozott, mivel a Készenléti Rendőrség az Őrezredével azonos hatáskörrel és illetékességgel rendelkezett, ${ }^{27}$ az Őrezred feladatait és szervezeti elemeit pedig a KR Személy- és Objektumvédelmi Igazgatóságba integrálták. A terület intézményi stabilitása az integráció után is csak viszonylagos volt, mivel ekkor már javában zajlott az Országgyúlési Őrség (Őrség) létrehozásának előkészítése, ezzel együtt pedig a személy- és objektumvédelmi feladatkörök átalakítása. Az Országgyűlési Ôrség jogelődjének a Képviselőházi Örséget tekinti, amelyet az 1912. évi LXVII. törvénycikk hozott létre, és 1913-tól látta el az Országgyúléssel kapcsolatos őrzés-védelmi feladatokat. A Képviselőházi Őrséggel kapcsolatban érdemes megemlíteni, hogy a testület megszüntetésére hivatalosan soha nem került sor (amely egy sor legitimációs kérdést is felvet), ${ }^{28}$ eredeti rendeltetésének megfelelő müködése azonban a Képviselőház és az Őrség állományának feloszlásával 1945-ben mégis megszűnt.

$\mathrm{Az}$ Országgyülési Őrség - a Rendőrséghez hasonlóan - sarkalatos törvény (Ogytv. $)^{29}$ alapján lett létrehozva, fontos különbség azonban, hogy az Ájtv. rendvédelmi szervekre vonatkozó felsorolásában nem szerepel. ${ }^{30}$ Szervezeti és múködési szabályzata ${ }^{31}$ alapján az Őrség országos illetékességgel rendelkező, a házelnök közvetlen irányítása alatt álló, központi költségvetési, fegyveres szerv, amelynek feladatait az Ogytv. az alábbiak szerint határozza meg:

\footnotetext{
30/2011 (IX. 22.) BM rendelet a rendőrség szolgálati szabályzatáról.

62/2007. (XII. 23.) IRM rendelet a Rendőrség Szolgálati Szabályzatáról.

30/2011 (IX. 22.) BM rendelet 79. § (1) bekezdés a)-f) pontja.

A módosító rendelkezések 2012. július 1-jén léptek hatályba.

67/2007. (XII. 28.) IRM rendelet a Rendőrség szervei illetékességi területének megállapításáról, 2. § (2) bekezdés.

28 Nagy Tamás - Lippai Zsolt: Politikai és egyéb csatározások a Képviselőházban - a Képviselőházi Ôrség megalakulása és szerepe. Magyar Rendészet, (2021), 1. (megjelenés alatt); Parádi Ákos - Parádi József: Rendvédelmünk 1867-1945. 16. (megjelenés alatt).

29 2012. évi XXXVI. törvény az Országgyúlésről.

30 2010. évi XLIII. törvény a központi államigazgatási szervekről, valamint a Kormány tagjai és az államtitkárok jogállásáról, 1. § (5) bekezdés.

31 Az Országgyűlés Elnökének 6/2017. házelnöki rendelkezése az Országgyülési Ôrség Szervezeti és Múködési Szabályzatáról.
} 
„Az Országgyűlési Őrség feladata az Országgyűlés védelme, függetlenségének és külső befolyástól mentes múködésének biztosítása, tárgyalási rendjének fenntartásával összefüggő, az e törvényben meghatározott személyvédelmi, létesítménybiztosítási feladatok biztosítása, protokolláris díszelgési, valamint az elsődleges tűzoltási és túzbiztonsági feladatok ellátása." ${ }^{32}$

Az Őrség feladatköre igen széles skálán mozog, az Országgyűlés elnökének személyi védelme mellett ${ }^{33}$ kiterjed valamennyi, az Országgyúlés múködésének - akár külső befolyástól mentes - biztosításával kapcsolatos feladatra is, amelynek fontosságát az is jól mutatja, hogy a testület az Alaptörvényben megjelenő garanciákat ${ }^{34}$ kapott. Tevékenységének normatív hátterét az Országgyúlésről szóló 2012. évi XXXVI. törvény határozza meg, ugyanakkor a működésének részleteit bizonyos körben a rendészetért felelős miniszter által kiadott rendeletek szabályozzák. Személyvédelmi tevékenysége kapcsán külön érdemes kiemelni azt, hogy a szolgálati szabályzatában ${ }^{35}$ foglaltak szoros átfedést mutatnak a rendőrség szolgálati szabályzatában foglalt személyvédelmi feladatokkal (személyvédelmi szolgálati forma). Miután a házelnök személyi védelme - az Országgyúlési Őrség létrehozásával - kikerült a rendőrség feladatköréből, a különösen fontos személyek normatív fogalma is szúkült, ugyanis a 160/1996. (XI. 5.) kormányrendelet mellékletéből kikerült az Országgyưlés elnöke. ${ }^{36}$

A következő jelentős változás a védett személyekkel kapcsolatos feladatok végrehajtását érintette, ami kisebb szervezeti változásokat is eredményezett. 2015. április 1-jén a Készenléti Rendőrségen belül megalakult a Köztársasági Elnöki Ôrség, kifejezetten a köztársasági elnök állandó védelmével kapcsolatos személy- és objektumvédelmi feladatok ellátására. Az átszervezés érdekessége az, hogy azzal párhuzamosan, hogy a Köztársasági Elnöki Örség átvette a TEK-től e feladatkört, a legfőbb ügyész személyi védelmével kapcsolatos hatáskör átkerült a Terrorelhárítási Központhoz. ${ }^{37}$ $\mathrm{Az}$ átszervezés szakmailag ellentmondásos, többek között azért, mivel ez az állomány szervek közötti cseréjét is érintette, másrészt a főosztály jogállású Köztársasági Elnöki Őrség nem a KR Személy- és Objektumvédelmi Igazgatóságának részeként, hanem közvetlenül a Készenléti Rendőrség parancsnoka alá rendelt - főosztály jogállású - egységként kezdte meg múködését (intézményen belüli párhuzam).

A Terrorelhárítási Központ személyvédelemmelkapcsolatos térnyerésétjól mutatja, hogy a miniszterelnök, illetve a legfőbb ügyész védelme mellett a 160/1996. (XI. 5.)

\footnotetext{
2012. évi XXXVI. törvény az Országgyülésről 125. § (1) bekezdés.

33 Az Országgyülési Őrség - a személyvédelmi mellett - létesítménybiztosítási, protokolláris díszelgési, tárgyalási rendfenntartói, tűzoltási és tűzbiztonsági, valamint járőr- és őrszolgálati szolgálati ággal rendelkezik.

34 Magyarország Alaptörvénye (2011. április 25.) 5. cikk (9): „Az Országgyủlés biztonságáról országgyűlési őrség gondoskodik. Az Országgyúlési Őrség müködését az Országgyúlés elnöke irányítja."

35 84/2012. (XII. 28.) BM rendelet az Országgyülési Ôrség szolgálati szabályzatáról.

36 Mivel a 160/1996. (XI. 5.) kormányrendelet kizárólag a rendőrség (KR, TEK) tevékenységét szabályozza, így nem része az Országgyülési Őrség tevékenységét szabályozó jogszabályoknak.

37 Balla (2017) i. m. 53.
} 
kormányrendelet 2018-as módosítása után e szerv személyvédelmi feladatköre a külgazdasági és külügyminiszter védelmére is kiterjed. ${ }^{38}$

$\mathrm{Az}$ említett átalakítások révén az állami rendészet személyvédelmi területe két részre szakadt. A kettős rendszer egyik elemét a Rendőrség, ezen belül a Terrorelhárítási Központ és az ORFK-Készenléti Rendőrség jelenti. Ezek közel azonos jogszabályi háttérrel múködnek, amely magában foglalja a rendőrségi törvényt, a személyvédelmi rendeletet, valamint a szolgálati szabályzat személyvédelemre vonatkozó rendelkezéseit (40. és 57. cím) is. ${ }^{39} \mathrm{~A}$ két szerv együttműködésére vonatkozó rendelkezések kifejezett forrása a rendőrségi törvény. ${ }^{40} \mathrm{~A}$ Készenléti Rendőrség és a Terrorelhárítási Központ mellett a személyvédelem harmadik jelentős rendészeti szereplője az Országgyúlési Őrség, amely az előbbiekkel ellentétben nem rendvédelmi (rendőri) szerv, hanem a törvényhozás mellett működő fegyveres szervként működik. ${ }^{41} \mathrm{~A}$ hatályos szabályozás alapján ${ }^{42}$ a Terrorelhárítási Központ látja el a miniszterelnök, a legfőbb ügyész, valamint a külgazdasági és külügyminiszter személyi védelmét. Az ORFK-Készenléti Rendőrség a köztársasági elnök (Köztársasági Elnöki Ôrség), valamint az Alkotmánybíróság elnökének védelméért (Személy- és Objektumvédelmi Igazgatóság), míg az Országgyülési Őrség a házelnök védelmével kapcsolatos feladatokért felel. Az intézményi háttér tagoltsága mellett 2013 után a tevékenység szabályozása - igazodva az egyes szervek normatív hátteréhez, irányításához és feladatköréhez - is jelentős változáson esett át. Fontos megjegyezni, hogy a Készenléti Rendőrség esetében a különböző szervek párhuzamos múködése mellett megfigyelhető egy belső intézményi párhuzam is, ami a Köztársasági Elnöki Őrség létrehozásával jött létre. Ennek eredményeként e rendőri szerven belül két egymástól független személyvédelmi egység jött létre. Az egyik a Köztársasági Elnöki Őrség, amely a KR parancsnokának közvetlen alárendeltségében működik (főosztály jogállású szervezeti elemként), a másik pedig a Személy- és Objektumvédelmi Igazgatóságon belül múködő Személyvédelmi Főosztály. A terület széttagoltságát talán az érzékelteti legjobban, hogy az egyes személyvédelmi egységek képzése, az általuk rendszeresített felszerelések vagy a kényszerítő eszközök jellege (például fegyverzet típusa, gépjárművek, lövedékálló mellények stb.) még a Készenléti Rendőrségen belül sem egységes, ez pedig önmagában is jelentős kockázatot jelent.

38 120/2018. (VII. 4.) Korm. rendelet a védett személyek és a kijelölt létesítmények védelméről szóló 160/1996. (XI. 5.) Korm. rendelet módosításáról.

39 30/2011. (IX. 22.) BM rendelet a rendőrség szolgálati szabályzatáról.

40 1994. évi XXXIV. törvény 7/G. § (3) bekezdés.

41 Szalai András: A közigazgatási jog alapjai. Budapest, Dialóg Campus, 2020. 26.

42 Az Rtv. és a 160/1996. kormányrendelet a különösen fontos személyek normatív fogalmát használja, ezek azonban nem tartalmaznak rendelkezéseket a házelnökkel kapcsolatban, és nem képezik részét az Országgyúlési Őrség tevékenységét szabályozó normáknak. 


\section{4. Összegzés}

A rendészet és a személyvédelem területén az elmúlt tíz évben több változás történt, mint az azt megelőző két évtizedben. Jelentős revízión esett át az ágazati szabályozás, az intézményrendszer, illetve egyes tevékenységek is, köztük az állandó védelem (különösen fontos személyek védelme) is. Utóbbi egy olyan területe az állami rendészetnek, amelyet 2010 előtt viszonylagos stabilitás jellemzett, amelynek eredményeképp a védett személyek köre, illetve a végrehajtásért felelős szerv (Köztársasági Őrezred) nem változott. Azt ugyan nem lehet egyértelműen kijelenteni, hogy a terület szakmai átalakítása indokolatlan lett volna, hiszen - leszámítva a rendvédelmen belüli átszervezéseket - a személyvédelem rendészeti alapjait a szocializmus évtizedeiben fektették le. A reformtörekvések jegyében 1990 és 1996 között a terület működése szorosan követte a demokratikus átalakulást, mélyreható reform azonban nem valósult meg. ${ }^{43} \mathrm{Az} 1990$-es évek második felétől viszonylagos stabilitás következett, ami 2010 után gyökeresen megváltozott. Egymást követték a szervezeti, múködési és szabályozási változások, amelyek eredményeként a személyvédelem napjainkra elvesztette korábbi, egységes jellegét, és kialakult egy párhuzamosan múködő intézményi háló, eltérő jellegű és rendeltetésű szervekkel.

A terület átalakítása - figyelembe véve a normatív háttér rendezetlenségét - nem tűnik befejezettnek, emellett pedig hatékonysága is megkérdőjelezhető, mivel az átalakulás a korábbi szervezeti struktúrát csak széttagolta, úgy alakítva ki egymással versengő elemeket a szervezetrendszeren belül, hogy azt hatékonysági vagy financiális szempontok nem indokolták. Az önmagában is ellentmondásos helyzetet tovább erősíti a védett személyek körének folyamatos változása, amely látszólag ad hoc jelleggel - az egyes szervek szakmai térnyerése alapján - valósul meg. Az állami vezetők védelmének elrendelése, megszüntetése, vagy éppen a feladat- és hatáskörök - szervek közötti - átrendezése azt a látszatot kelti, hogy az elmúlt években a terület szakmai átalakítása valódi ágazati stratégia nélkül valósult meg.

\section{IRODALOMJEGYZÉK}

Balla Zoltán: A rendészet alapjai és egyes ágazatai. Budapest, Dialóg Campus, 2017.

Christián László: A rendőrségre és a titkosszolgálatokra vonatkozó szabályozás változásai. MTA Law Working Papers, (2014), 43. 1-12.

Finszter Géza: Rendészettan. Budapest, Dialóg Campus, 2018.

Nagy Tamás - Lukács Zsolt: A személyvédelem rendészeti jellemzői és magánbiztonsági szerepe. In Christián László - Major László - Szabó Csaba (szerk.): Biztonsági vezetői kézikönayv. Budapest, Ludovika Egyetemi Kiadó, 2019. 165-196.

Nagy Tamás - Lippai Zsolt: Politikai és egyéb csatározások a Képviselőházban - a Képviselőházi Őrség megalakulása és szerepe. Magyar Rendészet, (2021), 1. 41-52. Online: https://doi. org/10.32577/mr.2021.1.3

$43 \quad$ Finszter (2018) i. m. 363. 
Parádi Ákos - Parádi József: Rendvédelmünk 1867-1945. (megjelenés alatt)

Szalai András: A közigazgatási jog alapjai. Budapest, Dialóg Campus, 2019.

Verebélyi Imre (szerk.): Rendszerváltozás és modernizáció a belügyi közigazgatásban (1989-1994). Budapest, Dialóg Campus, 2020.

\section{Jogi források}

Magyarország Alaptörvénye (2011. április 25.)

2012. évi XXXVI. törvény az Országgyülésről

1994. évi XXXIV. törvény a Rendőrségről

1998. évi IV. törvény a vállalkozás keretében végzett személy- és vagyonvédelmi, valamint a magánnyomozói tevékenység szabályairól, a Személy-, Vagyonvédelmi és Magánnyomozói Szakmai Kamaráról

2001. évi LXXXV. törvény a büntetőeljárásban részt vevők, az igazságszolgáltatást segítők Védelmi Programjáról

2005. évi CXXXIII. törvény a személy- és vagyonvédelmi, valamint a magánnyomozói tevékenység szabályairól

2010. évi CXLVII. törvény egyes rendészeti tárgyú és az azokkal összefüggő törvények módosításáról

87/1995. (VII. 14.) Korm. rendelet a vállalkozás keretében végzett személy- és vagyonvédelmi, valamint a magánnyomozói tevékenység átmeneti szabályairól

160/1996. (XI. 05.) Korm. rendelet a védett személyek és a kijelölt létesítmények védelméről

329/2007. (XII. 13.) Korm. rendelet a rendőrség szerveinek feladat- és hatásköréről

232/2010. (VIII. 19.) Korm. rendelet a Terrorelhárítási Központról

295/2010. (XII. 22.) Korm. rendelet a terrorizmust elhárító szerv kijelöléséről és feladatai ellátásának részletes szabályairól

83/2015. (III. 31.) Korm. rendelet egyes kormányrendeleteknek a köztársasági elnök személyvédelmének ellátásával összefüggő módosításáról

120/2018. (VII. 4.) Korm. rendelet a védett személyek és a kijelölt létesítmények védelméről szóló. 160/1996. (XI. 5.) Korm. rendelet módosításáról

69/1997. (XII. 29.) BM rendelet a Köztársasági Őrezred feladatáról, hatáskörésől és illetékességéről 30/2011. (IX. 22.) BM rendelet a rendőrség szolgálati szabályzatáról

31/2012. (VI. 28.) BM rendelet a Köztársasági Ôrezred megszüntetésével és más rendészeti tárgyú szervezeti változásokkal összefüggésben egyes miniszteri rendeletek módosításáról

84/2012. (XII. 28.) BM rendelet az Országgyűlési Ôrség szolgálati szabályzatáról

67/2007. (XII. 28.) IRM rendelet a Rendőrség szervei illetékességi területének megállapításáról

19/2013. (V. 17.) ORFK utasítás a Magyarország érdekei szempontjából különösen fontos személyek védelmének, a kijelölt létesítmények őrzésének rendőrségi feladatairól

53/1990. BM utasítás a Belügyminisztérium szervezetéről és belső rendjéről

Az Országgyúlés Elnökének 6/2017. házelnöki rendelkezése az Országgyưlési Őrség Szervezeti és Működési Szabályzatáról 


\section{ABSTRACT}

\section{Personal Protection Tasks of the Police - A Review of the Last 10 Years}

Tamás NAGY

The last ten years of public policing have been characterised by a continuous change, ranging from changes in tasks and competencies to the creation of new institutions. There are few areas of the Hungarian police force whose transformation was as diverse as in the case of personal protection. In the last ten years, not only the legal environment (regulation), but also the previous infrastructure (organisation) and the tasks (operation) have changed radically. The process has completely transformed the background of personal protection, which - in some aspects - could be determined as a reform. The protection of public figures is one of the least known areas of law enforcement, however, its importance is undisputed. The aim of this study is to briefly present the changes of personal protection in recent years and its impact on the operation of the area after 2010.

Keywords: personal protection, public policing, police force, public figure, Rapid Response and Special Police Services, Parliamentary Guard, Counter Terrorism Centre 